\title{
Progesterone, oestradiol-17 $\beta$ and LH during the oestrous cycle of muskoxen (Ovibos moschatus)
}

\author{
J. E. Rowell and P. F. Flood \\ Department of Veterinary Anatomy, Western College of Veterinary Medicine, \\ University of Saskatchewan, Saskatoon, Saskatchewan, Canada S7N OWO
}

\begin{abstract}
Summary. Progesterone, oestradiol-17 $\beta$ and LH were measured in plasma from 6 non-pregnant, captive, female muskoxen during the 1984 and 1985 breeding seasons. Jugular blood samples were taken on an alternating 3/4-day schedule in 1984 and daily or at 4-h intervals over oestrus, via indwelling jugular cannulae, for 6 weeks in 1985. Oestrous cycle length was $19 \cdot 6 \pm 0.96$ (s.d.) days $(n=19)$ and did not vary between the first and subsequent cycles of the season. Progesterone was lowest at oestrus $(\leq 0.1 \mathrm{ng} / \mathrm{ml}$ ), began to rise on Days 4-5, peaked on Days $10-12($ mean $=2.6 \mathrm{ng} / \mathrm{ml}$ ) and returned to baseline 2-5 days before the next oestrus. A small rise in progesterone before the first cycle of the breeding season was observed on 7 of 12 occasions. Oestradiol-17 $\beta$ was significantly higher $(P<0.001) 1-4$ days before, or coincident with, oestrus. The average duration of the LH peak was $24 \cdot 6 \mathrm{~h}(n=7)$ and coincided with observations of behavioural oestrus. In one animal behavioural oestrus and an LH peak preceded a small progesterone rise at the beginning of the breeding season. The temporal relationship of these three hormones during the muskox oestrous cycle is very similar to that seen in domestic ruminants.
\end{abstract}

Keywords: muskox; oestrous cycle; progesterone; oestradiol-17ß; LH

\section{Introduction}

Although superficially resembling bison, muskoxen have many characteristics in common with sheep and goats (Moody, 1958; Tener, 1965; Rowell et al., 1987) and are in the same subfamily (Caprinae) (Simpson, 1945). However, their lack of close relatives, chromosomal differences $(2 \mathrm{~N}=48)$ and adaptation to an arctic environment make this species of particular comparative interest.

The morphology of the muskox reproductive tract is very similar to that of sheep and goats but little is known of their reproductive physiology. Most information has come from behavioural observations (Gray, 1987) and post-mortem examination (Tessaro et al., 1984; Rowell et al., 1987). Muskoxen are seasonally polyoestrous, generally mating in August (Tener, 1965; Tessaro et al., 1984; Latour, 1987) and September (Smith, 1976; Gray, 1987) in their natural habitat. The oestrous cycle of the muskox is estimated to be 21 days in length (J. Bourque, cited by Gray, 1973; Wilkinson, 1973) but nothing is known of its endocrinology. Accordingly, serial blood samples were taken from 6 captive muskoxen over 2 breeding seasons to measure changes in progesterone, oestradiol-17 $\beta$ and luteinizing hormone $(\mathrm{LH})$ during the oestrous cycle.

\section{Materials and Methods}

Animals. Six adult, female, muskoxen from the Research Herd at the Western College of Veterinary Medicine (Flood et al., 1984) were sampled over 2 breeding seasons (1984-1985). They were 2.5 years old at the beginning of the study and 5 of the 6 females were parous. The females were kept together in outdoor pens with intact and castrated males. They were fed a supplement of oat pellets and had ad-libitum access to brome-alfalfa hay and water. The muskoxen had been bottle raised and were fully accustomed to handling and restraint. 
Sample collection. In 1984, blood samples were collected on an alternating 3/4-day schedule and the cows were allowed to mate freely with the dominant bull.

In 1985, the cows were fitted with jugular cannulae about 1-2 weeks before the first expected oestrus. Following immobilization with carfentanil (Janssen Pharmaceuticals, Mississauga, Ontario, Canada) and xylazine (HaverLockhart, Rexdale, Ontario, Canada), one jugular vein was cannulated. Immobilization was reversed with naloxone (Wildlife Labs Ltd, Fort Collins, CO, U.S.A.) after 20-40 min. The cannulae were flushed and refilled with heparinized saline (10 U heparin $/ \mathrm{ml}$ physiological saline) twice daily and following each blood collection. Prophylactic antibiotics were administered at the time of cannulation and again 3 weeks later.

Daily blood samples were collected until oestrus was detected, then samples were taken at $4-\mathrm{h}$ intervals for $3648 \mathrm{~h}$ to detect the LH peak. The cannulae remained patent for 2-6 weeks. Those that blocked before the end of the trial were removed and blood was taken by jugular venepuncture every second day. After 6 weeks the two remaining cannulae were removed and sampling in all animals was continued on the alternating 3/4-day schedule until the next observed oestrus when the females were allowed to mate with a fertile male.

Daily samples $(\sim 10 \mathrm{ml})$ were collected between 09:00 and 12:00 h in heparinized vacutainers, refrigerated immediately and centrifuged at $2500 \mathrm{~g}$ for $10 \mathrm{~min}$ within $1 \mathrm{~h}$ of collection to optimize progesterone preservation (Rowell \& Flood, 1987). Plasma was stored at $-22^{\circ} \mathrm{C}$ until assayed. All samples were assayed for progesterone and the 1985 samples were also assayed for $\mathrm{LH}$ and oestradiol-17 $\beta$.

Detection of oestrus. In 1984 white adhesive tape was fixed to the rump hair of females and coloured petroleum jelly applied to the briskets of the bulls. Continuous observations for evidence of oestrus were made between 16:00 and 17:00 $\mathrm{h}$ each day and the cows were checked each morning for colour marking.

In 1985, an experienced bull was vasectomized, his brisket was painted and the cows were taped as before. The cows were separated from the rest of the herd during the day $(09: 00-16: 00 \mathrm{~h})$ after which they were placed with the vasectomized bull and a $1-h$ check for oestrus was conducted. The cows were left with the bull overnight and checked for colour marks the following morning. The first day of oestrus, indicated by behaviour and colour marking, was designated Day 0.

Hormone assays. Progesterone, oestradiol-17ß and LH were measured by radioimmunoassays (RIA) following the methods of Rawlings et al. (1984).

Progesterone was measured in duplicate samples using a double-antibody method and ${ }^{125}$ I-labelled progesterone. The antiserum (raised against 4-pregnen-1 1 $\alpha$-ol-3,20-dione hemisuccinate-BSA) (Steraloids Q3253) had the following cross-reactions: $5 \beta$-pregnan-3,20-dione, $20 \% ; 5 \alpha$-pregnan-3,20-dione, $14 \%$; corticosterone, $0 \cdot 8 \%$. The reaction was stopped using a sheep anti-rabbit $\gamma$-globulin solution. Extraction efficiency was $75 \pm 4 \%$ (mean \pm s.d., $n=19$ ). To confirm extraction efficiency from muskox plasma, 0.5 and $2.5 \mathrm{ng} / \mathrm{ml}$ progesterone were added to plasma of a castrated muskox. The samples $(n=4)$ were assayed as above and found to contain $0.64 \mathrm{ng} / \mathrm{ml}$ and $2.75 \mathrm{ng} / \mathrm{ml}$ $(\mathrm{CV}=11.3 \%$ and $3.0 \%$ respectively). The labelled ligand was significantly displaced from the antiserum by $5 \mathrm{pg}$ progesterone. Coefficients of variation were calculated from a high $(\sim 2.5 \mathrm{ng} / \mathrm{ml})$ and a low $(\sim 1.3 \mathrm{ng} / \mathrm{ml}) \mathrm{reference}$ pool of sheep plasma. The mean ( \pm s.d.) intra-assay coefficients of variation were $7 \cdot 4 \pm 4 \cdot 1 \%(n=18)$ and $9 \cdot 8 \pm 5 \cdot 4 \%(n=15)$ for high and low references respectively. The inter-assay coefficients of variation were $11 \cdot 7 \%$ ( $n=37$; high reference) and $14.6 \%(n=24$; low reference).

Oestradiol-17 $\beta$ was measured in $1-\mathrm{ml}$ samples of muskox plasma. The antiserum (raised in rabbits against 1,3,5,(10)-oestratriene-3,17ß-diol-6-one-6-O-carboxy-methyloxime-bovine serum albumin) had the following crossreactions: oestrone, $2.7 \%$; testosterone, $0.02 \%$; progesterone, $<0.02 \%$; cortisol, $<0.01 \%$. Extraction efficiency was $(85 \pm 1 \%, n=10)$. The labelled ligand was significantly displaced from the antiserum by 1 pg oestradiol-17 3 . The mean intra-assay coefficients of variation for a high and low concentration reference ewe plasma were $6 \cdot 7 \pm 3 \cdot 2 \%$ $(n=10)$ and $12 \cdot 1 \pm 1 \cdot 7 \%(n=10)$ respectively. Inter-assay variation was $10 \cdot 1 \%(n=30 ;$ high reference $)$ and $14 \cdot 1 \%$ $(n=37$; low reference).

LH concentrations were measured in duplicate samples using a double-antibody RIA (Rawlings et al., 1984). The first antibody was prepared in rabbits and had the following cross-reactions: ovine thyroid-stimulating hormone, $5 \%$; ovine FSH, 1.1\%; ovine prolactin, $0 \cdot 1 \%$; growth hormone, $3 \cdot 1 \%$. The range of the standard curve was $50 \mathrm{pg}-12 \cdot 8 \mathrm{ng}$ (NIH-LH-S18) and $100 \mathrm{pg} \mathrm{LH}$ significantly displaced the labelled ligand from the antiserum. The intra- and interassay coefficients of variation were $4.5 \%(n=17)$ and $16 \%(n=47)$ respectively.

The ovine $\mathrm{LH}$ assay was validated for muskoxen using muskox pituitary extract. Pituitaries from 2 muskox calves were homogenized in distilled water, centrifuged and the supernatant diluted 100-, 1000-, 10000-fold. The binding inhibition curve of the muskox pituitary extract was parallel to the inhibition curve of ovine LH.

Statistical analysis. Analysis of variance and Scheffe's test were used to detect significant differences in the oestradiol-17ß results (Snedecor \& Cochran, 1980).

\section{Results}

\section{The onset and length of the oestrous cycle}

Muskox cows showed their first signs of oestrus from 20 September to 8 October in both 1984 and 1985 (median breeding date, 25 September). 
In 1984,1 cow failed to conceive and blood samples were collected during 4 consecutive cycles. The remaining 5 cows conceived to the first oestrus. In 1985, 2 cycles were followed in each of 4 cows, 3 in another and 4 in a cow that failed to conceive. The 19 cycles for which complete hormonal data were obtained had a mean length of $19.6 \pm 0.96$ (s.d.) days (range 18-21 days). There was no difference in length between the first cycle of the season and subsequent cycles. No attempt was made to define the end of the breeding season but 1 infertile cow had a total of 7 oestrous cycles that continued until March. Frequent blood samples were not collected during the later cycles; these were inferred from oestrous behaviour and were not included in the hormone profiles.

\section{Progesterone concentrations}

The combined data for all 19 oestrous cycles are shown in Fig. 1. Jugular progesterone concentrations were lowest around the time of oestrus $(\leq 0.1 \mathrm{ng} / \mathrm{ml})$, began to rise above $0.4 \mathrm{ng} / \mathrm{ml}$ on Days $4-5$, peaking at $1 \cdot 4-5 \cdot 3 \mathrm{ng} / \mathrm{ml}$ on Days $10-12$ (mean $=2 \cdot 6 \mathrm{ng} / \mathrm{ml}$ ). Progesterone began to decline on Days 16-17 reaching basal levels 2-5 days before the next oestrus.

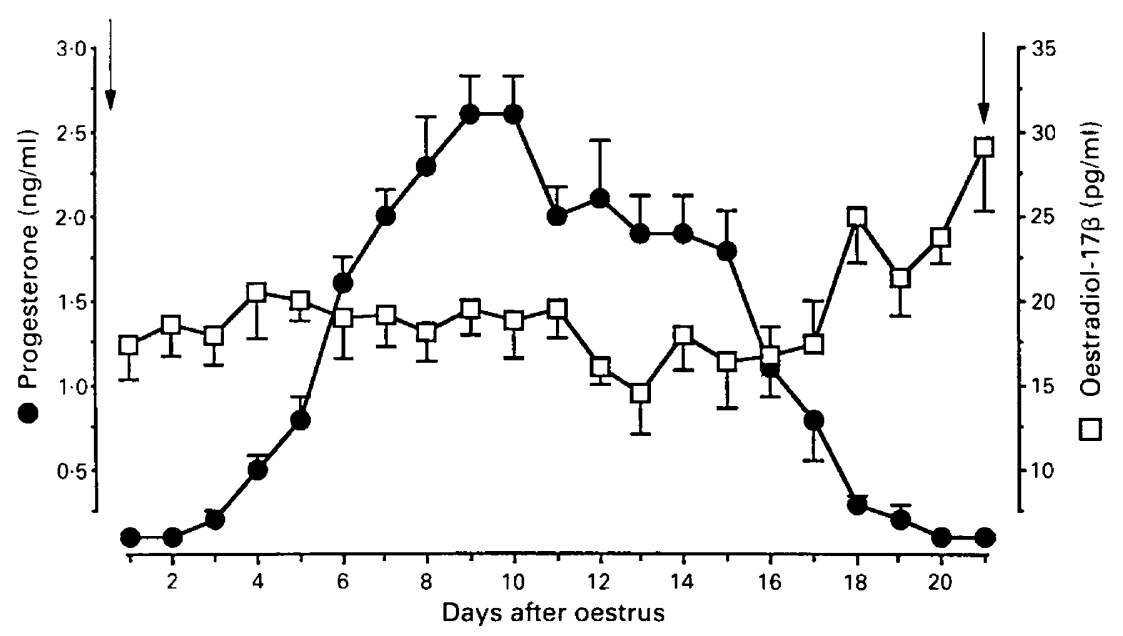

Fig. 1. The combined progesterone concentrations ( \pm s.e.m.) for 19 muskox oestrous cycles and oestradiol-17 $\beta$ concentrations ( \pm s.e.m.) for 14 oestrous cycles. All data have been normalized to the day of oestrus (Day 0 ), indicated by the arrows.

A small rise in progesterone $(\geq 0.4 \mathrm{ng} / \mathrm{ml}$ ) with a mean duration of 4.6 days was observed in 7 of 12 instances at the beginning of the breeding season. One cow had 2 such peaks (both with peak values of $0.7 \mathrm{ng} / \mathrm{ml}$ and both lasting 4 days) before the first normal cycle of 1985 .

\section{Oestradiol-17ß concentrations}

Mean values for oestradiol-17 $\beta$ from 14 cycles are shown in Fig. 1. The concentrations on the day of oestrus and the preceding 4 days were significantly higher $(P<0.001)$ than those at other times during the cycle. Minimum values were seen in the mid- and late luteal phase.

\section{LH concentrations}

The frequent sampling period encompassed the LH peak in 7 cycles from 5 different cows. It occurred 5, 4 and 2 days after progesterone had returned to baseline $(0.4 \mathrm{ng} / \mathrm{ml})$ (Fig. $2 \mathrm{a} \& \mathrm{~b})$. The 
average duration of $7 \mathrm{LH}$ peaks was $24.6 \mathrm{~h}$ (range $20-28 \mathrm{~h}$ ). The detected amplitude varied from 7.9 to $20.6 \mathrm{ng} / \mathrm{ml}$. Of the $7 \mathrm{LH}$ peaks recorded, 6 coincided with Day 0 of the cycle. In the 7 th case the LH peak coincided with behavioural oestrus but was followed by only a slight rise in progesterone $(0.7 \mathrm{ng} / \mathrm{ml})$ and the cow returned to oestrus 8 days later. Unfortunately, the cannula in this cow became blocked and $\mathrm{LH}$ could not be measured at the second oestrus. Progesterone concentrations indicated that the subsequent cycle was of normal length.
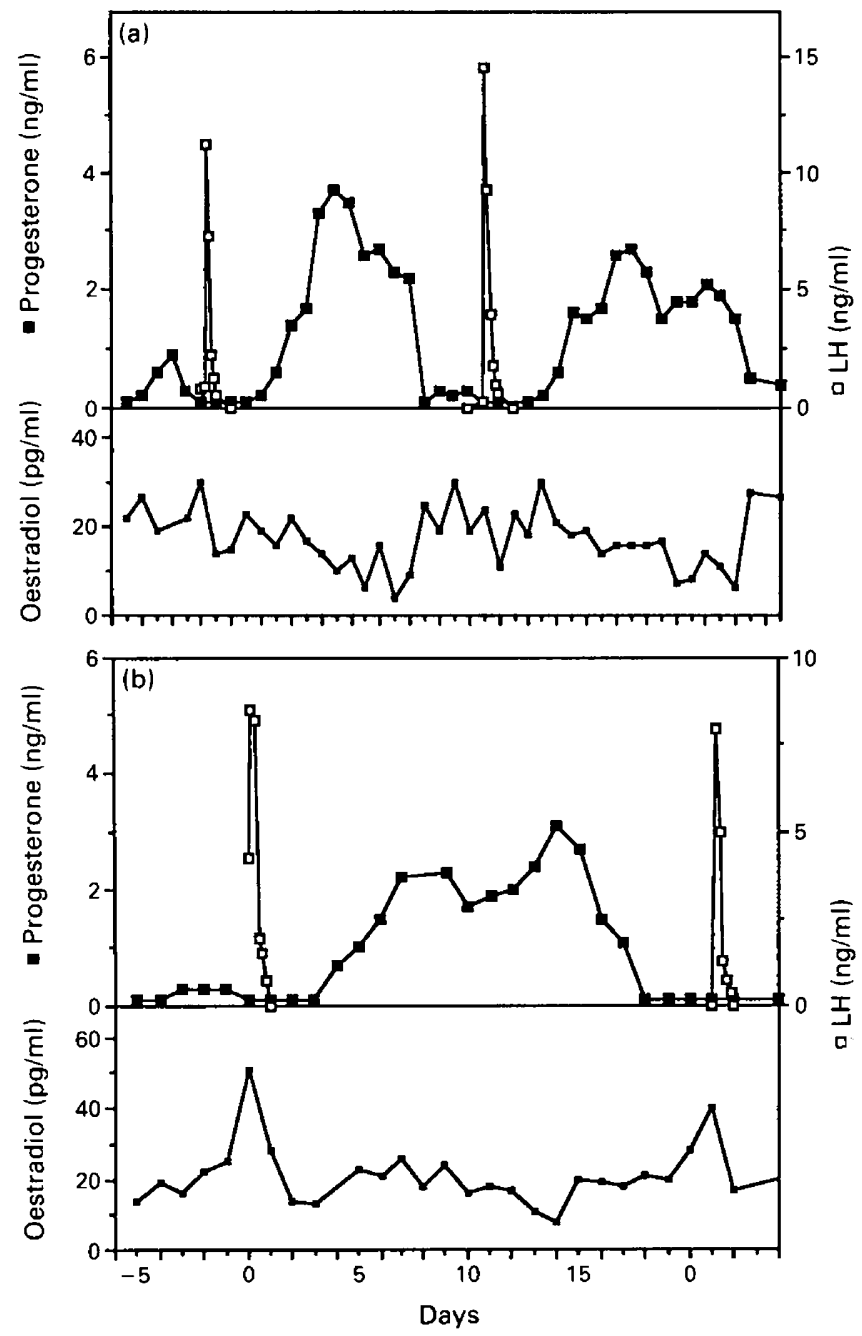

Fig. 2. Representative progesterone, oestradiol-17 $\beta$ and LH profiles for 2 muskoxen (a, b) during the oestrous cycle. The day of oestrus is Day 0 . The days preceding the first oestrus are shown as negative values.

\section{Discussion}

The 19.6-day oestrous cycle, based on peripheral progesterone concentrations, agrees well with behavioural observations of a 21-day cycle in captive muskoxen at Kuujjuaq, Quebec (J. Bourque, cited in Gray, 1973) and the 19-21-day cycle inferred from the temporal spacing of births of captive 
muskoxen in Alaska (Wilkinson, 1973). Although red deer and Père David's deer have an average cycle length of 20 days, considerably longer cycles may occur (Guinness et al., 1971; Curlewis et al., 1988). In fallow deer there is a tendency for the cycle to lengthen as the breeding season progresses (Asher, 1985). Large variations in cycle length were not evident here, although only 4 sequential cycles were intensively studied in a season. The animals were all the same age and their calves had been weaned 1.5-2 months before the breeding season and so the effect of age and lactation could not be assessed.

The changes in progesterone concentration in peripheral plasma were similar to those reported in the ewe (Yuthasastrakosol et al., 1975), cow, buffalo and zebu (see Dobson \& Kamonpatana, 1986), red deer (Adams et al., 1985), fallow deer (Asher, 1985) and Père David's deer (Curlewis et al., 1988). A small progesterone rise at the onset of the breeding season is characteristic of many seasonally breeding species (sheep: Legan et al., 1985; fallow deer: Asher, 1985) with the exception of the red deer (Guinness et al., 1971; Adams et al., 1985). The rise has been associated with fluctuating LH levels in ewes (Yuthasastrakosol et al., 1975) and roe deer (Schams et al., 1980) and silent ovulation in other cervids (Asher, 1985). In the ewe, a brief rise in progesterone at the beginning of the breeding season is sufficient to provide the progesterone priming essential for normal luteal function (Legan et al., 1985). Similar mechanisms may be acting in the muskox.

The raised concentrations of oestradiol- $17 \beta$ in the muskox just before or during oestrus and minimum values in the mid- and late luteal phase are similar to those in sheep (Karsch et al., 1979), cattle (Dobson \& Kamonpatana, 1986) and white-tailed deer (Plotka et al., 1980). A rise in oestradiol-17 $\beta$ was seen in some cows 3-4 days after oestrus. Its occurrence was too irregular to be demonstrable in the pooled data.

The preovulatory LH peak occurred 2-5 days after progesterone had reached baseline. This period is apparently longer and more variable than in the ewe (Baird \& Scaramuzzi, 1976; Karsch et al., 1979), goat (Mori \& Kano, 1984) and cow (Walters \& Schallenberger, 1984). The duration of the LH surge $(24 \mathrm{~h})$ was longer than the 6-10 h reported for cattle (Walters \& Schallenberger, 1984), 7-8 h for goats (Mori \& Kano, 1984) or $14 \mathrm{~h}$ for the ewe (Pant et al., 1977). In roe deer the LH peak occurred over a period of days (Schams et al., 1980).

Overall, the pattern and temporal relationships of progesterone, oestradiol-17 $\beta$ and $\mathrm{LH}$ in the muskox are very similar to those reported for domestic ruminants, suggesting that mechanisms for the control of ovulation and luteolysis are similar.

Like sheep, muskoxen are seasonal breeders. In both years of this study the onset of the breeding season was 4-6 weeks later than the estimated time of breeding on Banks Island, Northwest Territories (the island on which these animals were originally captured) (Tessaro et al., 1984; Latour, 1987). Calving dates from other southern locations also indicate delayed onset of breeding (Teal, 1959; Oeming, 1965; Karsten, 1986; Dr G. Glover, Assiniboine Park Zoo, Winnipeg, personal communication). Although this difference could be a consequence of captivity, the effects of temperature and latitude $\left(\sim 20^{\circ}\right.$ difference) cannot be excluded. Throughout their natural range, breeding begins at approximately the same time in either decreasing (Thelon Game Sanctuary) or continuous (Northern Ellesmere Island) daylight, suggesting that the stimulus initiating breeding in muskoxen is different from the decreasing photoperiod effective in sheep, goats and deer. Tener (1965) has proposed that the alternating light and dark of the vernal equinox may provide the photostimulatory cue. Given the general similarities between muskoxen and sheep, it would be particularly interesting to investigate this hypothesis and the mechanisms governing the onset of breeding in muskoxen.

The research herd was established with a grant from the Donner Canadian Foundation. The study was supported by the National Sciences and Engineering Research Council Operating Grant A2759 and Infrastructure Grant A2793. Samples were assayed by Reproductive Endocrine Assay Systems, Reproductive Endocrine Laboratory, Western College of Veterinary Medicine, Saskatoon. We thank C. Stevens for her skilled and dedicated care of the animals and N. Rawlings and S. Cooke for advice and assistance with the assays. 


\section{References}

Adams, C.L., Moir, C.E. \& Atkinson, T. (1985) Plasma concentration of progesterone in female red deer (Cervus elaphus) during the breeding season, pregnancy and anoestrus. J. Reprod. Fert. 74, 631-636.

Asher, G.W. (1985) Oestrous cycle and breeding season of farmed fallow deer, Dama dama. J. Reprod. Fert. $75,521-529$.

Baird, D.T. \& Scaramuzzi, R.J. (1976) Changes in the secretion of ovarian steroids and pituitary luteinizing hormone in the peri-ovulatory period in the ewe: the effect of progesterone. J. Endocr. 70, 237-245.

Curlewis, J.D., Loudon, A.S.I. \& Coleman A.P.M. (1988) Oestrous cycles and the breeding season of the Père David's deer hind (Elaphurus davidianus). J. Reprod. Fert. 82, 119-126.

Dobson, H. \& Kamonpatana, M. (1986) A review of female cattle reproduction with special reference to a comparison between buffaloes, cows and zebu. $J$. Reprod. Fert. 77, 1-36.

Flood, P.F., Rowell, J.E., Glover, G.J., Chaplin, R.K. \& Humphreys, S. (1984) The establishment of a small research herd of captive muskoxen. Biol. Pap. Univ. Alaska Spec. Rep. No. 4, 170-172.

Gray, D.R. (1973) The social organization and behaviour of muskoxen (Ovibos moschatus) on Bathurst Island, N.W.T. Ph.D. thesis, University of Alberta, Edmonton.

Gray, D.R. (1987) The Muskoxen of Polar Bear Pass. Fitzhenry and Whiteside, Markham, Ontario.

Guinness, F., Lincoln, G.A. \& Short, R.V. (1971) The reproductive cycle of the female red deer, Cervus elaphus L. J. Reprod. Fert. 27, 424438.

Karsch, F.J., Foster, D.L., Legan, S.J., Ryan, K.D. \& Peter, G.K. (1979) Control of the preovulatory endocrine events in the ewe: interrelationship of estradiol, progesterone and luteinizing hormone. Endocrinology 105, 421-426.

Karsten, P. (1986) Fifteen years of experience in keeping muskox (Ovibos moschatus) at the Calgary Zoo. Zool. Garten N. F. 56, 241-261.

Latour, P.B. (1987) Observations on demography, reproduction and morphology of muskoxen (Ovibos moschatus) on Banks Island, Northwest Territories. Can. J. Zool. 65, 265-269.

Legan, S.J., l'Anson, H., Fitzgerald, B.P. \& Akaydin, M.S. (1985) Importance of short luteal phases in the luteal mechanism controlling initiation of estrous cycles in anestrous ewes. Endocrinology 117, 1530-1536.

Moody, P.D. (1958) Serological evidence on the relationships of the muskox. J. Mammal. 39, 554-559.

Mori, Y. \& Kano, Y. (1984) Changes in plasma concentrations of $\mathrm{LH}$, progesterone and oestradiol in relation to the occurrence of luteolysis, oestrus and time of ovulation in the Shiba goat (Capra hircus). $J$. Reprod. Fert. 72, 223-230.

Oeming, A. (1965) A herd of muskoxen (Ovibos moschatus) in captivity. Int. Zoo Yearbook 5, 58-65.
Pant, H.C., Hopkinson, C.R.N. \& Fitzpatrick, R.J. (1977) Concentration of oestradiol, progesterone, luteinizing hormone and follicle-stimulating hormone in the jugular venous plasma of ewes during the oestrous cycle. J. Endocr. 73, 247-255.

Plotka, E.D., Seal, U.S., Verme, L.J. \& Ozoga, J. J. (1980) Reproductive steroids in deer. III. Luteinizing hormone, estradiol and progesterone around estrus. Biol. Reprod. 22, 576-581.

Rawlings, N.C., Jeffcoate, I.A. \& Reiger, D.L. (1984) The influence of estradiol-17 $\beta$ and progesterone on peripheral serum concentrations of luteinizing hormone and follicle stimulating hormone in the ovariectomized ewe. Theriogenology, 22, 473-488.

Rowell, J. \& Flood, P.F. (1987) Changes in muskox blood progesterone between collection and centrifugation. J. Wildl. Mgmt 51, 902-903.

Rowell, J., Betteridge, K.J., Randall, G.C.B. \& Fenwick, J.C. (1987) Anatomy of the reproductive tract of the female muskox (Ovibos moschatus). J. Reprod. Fert. 80, 431-444.

Schams, D., Barth, D. \& Karg, H. (1980) LH, FSH and progesterone concentrations in peripheral plasma of the female roe deer (Capreolus capreolus) during the rutting season. J. Reprod. Fert. 60, 109-114.

Simpson, G.G. (1945) The principles of classification and a classification of mammals. Bull. Am. Nat. Hist. 85, 1-350.

Smith, T.E. (1976) Reproductive behaviour and related social organization of the muskox on Nunivak Island. M.S. thesis, University of Alaska, Fairbanks.

Snedecor, G.W. \& Cochran, W.G. (1980) Statistical Methods. The Iowa State University Press, Ames, Iowa.

Teal, J.J., Jr (1959) Musk ox in rut. Polar Notes 1, 65-71.

Tener, J. (1965) Muskoxen in Canada. A Biological and Taxonomic Review. Queens Printer, Ottawa, Canada.

Tessaro, S., Rowell, J.E., Cawthorn, R. \& Latour, P. (1984) Banks Island muskox harvest, 1982. Biol. Pap. Univ. Alaska Spec. Rep. No. 4, 177-180.

Walters, D.L. \& Schallenberger, E. (1984) Pulsatile secretion of gonadotrophins, ovarian steroids and ovarian oxytocin during the periovulatory phase of the oestrous cycle in the cow. J. Reprod. Fert. 71, 503-512.

Wilkinson, P.F. (1973) The relevance of muskox exploitation to the study of prehistoric animal economics. Ph.D. thesis, Cambridge University.

Yuthasastrakosol, P., Palmer, W.M. \& Howland, B.M. (1975) Luteinizing hormone, oestradiol-17 $\beta$ and progesterone levels in peripheral serum of anoestrous and cyclic ewes as determined by radio-immunoassay. J. Reprod. Fert. 43, 57-65. 